NEW ZEALAND TYNDALE LEGTURE, I 966

\title{
PAUL AND JERUSALEM
}

By F. F. BRUGE

The purpose of this paper is not to examine the thesis so cogently defended of late by Professor W. C. van Unnik that Jerusalem, and not his native Tarsus, was the city of Paul's boyhood and upbringing, ${ }^{1}$ but rather to consider the place which Jerusalem occupied in Paul's apostolic strategy and in his understanding of the outworking of the divine programme in which he himself had a key part to play. Our evidence will be drawn mainly from Paul's epistles, although the narrative of Acts will make a subsidiary contribution to it at certain points.

\section{I}

'From Jerusalem', says Paul towards the end of his Epistle to the Romans, 'and as far as Illyricum, I have fully preached the gospel of Christ' (Rom. I 5:19).

But for this brief reference, we should not have known that he had travelled so far west as Illyricum by the winter of $\mathrm{AD}$ 56-57. It should probably be inferred that his visit to Macedonia, passed over quickly in general terms in Acts 20:2 ('when he had gone through these parts and had given them much encouragement'), was more extended than we might otherwise have thought-that on this occasion he travelled farther west and north-west through the Balkan Peninsula than he had ever done before, reaching the frontier of Illyricum and perhaps even crossing into that province. ${ }^{2}$

The mention of Illyricum, then, presents us with an interesting question. But a question of another kind arises in the same sentence: why the reference to Jerusalem, as though that was the place where he began to preach the gospel? So far as we can judge from the autobiographical outline in Galatians I: $15 \mathrm{ff}$.,

1 W. C. van Unnik, Tarsus or Ferusalem: The City of Paul's Youth, Eng. tr., Epworth Press, London (1962).

'Such a journey may be contemplated in his reference to the 'lands beyond you' in 2 Cor. 10:16. 
it was not. Paul does not say there in so many words that as soon as he received the call to proclaim the Son of God among the Gentiles he proceeded to obey it, before he went up to Jerusalem in the third year after his conversion; but this is implied both by his words 'I did not confer with flesh and blood' (Gal. I:16) and perhaps also by his later statement that the Judaean churches, before ever they came to know him by sight, heard that their former persecutor was now proclaiming the faith which he once tried to destroy (Gal. I:22ff.). ${ }^{3}$

For Paul, in fact, as for Luke, Jerusalem is the place where the gospel begins. ${ }^{4}$ At the end of his Gospel Luke speaks of the forthcoming proclamation of repentance and forgiveness in Christ's name to all the nations, 'beginning from Jerusalem' (Lk. 24:47). So, at the outset of his second volume, he tells how the risen Christ commissioned His apostles to be His witnesses 'in Jerusalem and in all Judaea and Samaria and to the end of the earth' (Acts $\mathrm{I}: 8$ ).

Paul, for his part, looks on Jerusalem as the earthly metropolis of the new Israel. In one place, indeed, he does distinguish 'the present Jerusalem' from 'the Jerusalem above' which, he says, 'is free, and she is our mother' (Gal. 5:25f.). But there it is not so much the geographical Jerusalem that 'is in slavery with her children' as the Jewish religion, which was centred in Jerusalem. For practical purposes, however, the geographical Jerusalem is for Paul the metropolis on earth of the new Israel in the sense that the people of God there constitute the mother-church of all believers. The people of God in Jerusalem are 'the saints' in a primary sense; more than once in his references to the collection for Jerusalem Paul speaks of 'the contribution for the saints' without qualification (e.g. I Cor. I6:I). ${ }^{5}$ If Gentile Christians are also 'saints' (as they certainly are) it is because they have become 'fellow citizens with the [original] saints and members [with them] of the household of God' (Eph. 2:19).

- This refers primarily to his evangelistic activity in Syria and Cilicia after his first post-conversion visit to Jerusalem, but that was not the beginning of his evangelistic activity.

4 When he asks the Corinthians ironically 'Did the word of God originate with you?' (i Cor. 14:36), the implication may be that, in fulfilment of the prophecy of Is. 2:3 and Mi. 4:2, it is from Jerusalem that the $\lambda$ ó yos rov kvpiov goes forth. See B. Gerhardsson, Memory and Manuscript, G. W. K. Gleerup, Lund (196r) $273 \mathrm{ff}$.

' $C f_{.} 2$ Cor. 9:I; also Rom. 15:25, $3^{1}$ (although there 'Jerusalem' is mentioned explicitly in the same context as 'the saints'). 
Paul himself is independent of Jerusalem, as he repeatedly insists, yet he can never dissociate himself from Jerusalem. Dissociation from Jerusalem would imply in practice severance from the birthplace of Christianity; yet dependence on Jerusalem would be a denial of his receiving his apostolic call direct from Christ. This ambivalence in Paul's relationship with Jerusalem pervades his epistles - and it may be discerned in the record of Acts also. In Acts there is regularly trouble when Paul visits Jerusalem; the church of Jerusalem, one feels, must always have breathed a sigh of relief when Paul left the city after one of his visits. (One might even be tempted to think that there is more significance than meets the eye in the editorial note of Acts 9:3 I, after Paul's friends in Jerusalem have taken him down to Gaesarea and put him on board a ship bound for Tarsus: 'So the church ... had peace'.)

\section{II}

In the first two chapters of Galatians Paul is at pains to enumerate his visits to Jerusalem between his conversion and the time of writing this epistle. We need not be concerned at present about the correlation of these visits with Paul's Jerusalem visits recorded in Acts. ${ }^{6}$ The prime purpose of his listing them in Galatians is to show that on no occasion when he went to Jerusalem, or came in touch with the apostles and other leaders of the church there, did they confer any authority on him beyond what he already possessed by direct gift of Christ.

Nevertheless, he did go up to Jerusalem; why did he go at all? On the first occasion, he tells his readers, he went up 'to visit Gephas' and spent a fortnight with him. The only other 'apostle' whom he met at that time was James-not James the Zebedaean, although he was still alive, but 'James the

- The visit of Gal. I:18ff. may certainly be identified with that of Acts 9:26ff., despite some differences in the details of the two accounts. The visit of Gal. 2: $1 \mathrm{ff}$. has been identified with that of Acts $11: 30$ (e.g. by John Calvin, Commentary on Galatians, 1548, Eng. tr., Oliver and Boyd, Edinburgh (1965) 24); with that of Acts I 5:2ff. (the commonest view; $c f . J$. B. Lightfoot, Galatians, Macmillan, London (18go) 125f.); with both, on the hypothesis that Luke, relying on two distinct sources, has made two visits out of one ( $c f . \mathrm{J}$. Wellhausen, Nachrichten der königlichen Gesellschaft der Wissenschaften zu Göttingen, phil.-hist. Klasse, 1907, Iff., and E. Schwartz, ibidem, $263 \mathrm{ff}$.) ; with that of Acts 18:22 (e.g. by J. Knox, Chapters in a Life of Paul, Abingdon-Cokesbury Press, Nashville (1950) 64ff.); with a visit unrecorded in Acts, located between verses 2 and 3 of Acts I3 (by T. W. Manson, Studies in the Gospels and Epistles, Manchester University Press (1962) 1 76f.). 
Lord's brother' (Gal. I:I8f.). But what precisely is meant by

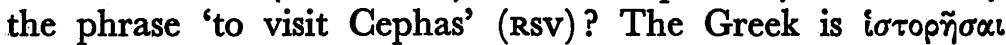

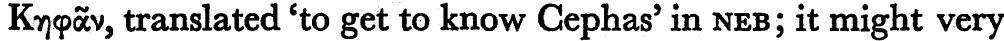
well mean 'to inquire of Cephas'. W. D. Davies devotes an appendix of his book The Setting of the Sermon on the Mount to

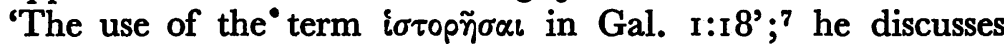
various suggestions, and finds J. Wagenmann's approach to be a helpful one: 'He distinguishes between Paul's desire to learn


on Paul's part that he was seeking recognition from Peter.'8 Paul himself at least recognized Peter as a primary informant on matters regarding which it was now important that he should be well informed-the facts about Jesus' ministry, the 'tradition' or deposit of teaching which derived its authority from Him, that 'tradition' concerning which Paul could later say to his converts, 'I delivered to you ... . what I also received' (I Cor. I 5:3; $c f$. I I:23). ${ }^{9}$ Peter could obviously impart to Paul much in the way of such information-more indeed than James could, since James had not been a companion of Jesus during His public ministry-but one thing, Paul insists, Peter did not and could not impart to him, and that was apostolic authority. Yet he went to Jerusalem, both to maintain fellowship with the mother church and its leaders and also to obtain in Jerusalem what he could obtain nowhere else. ${ }^{10}$

Paul must certainly have distinguished in his own mind between the sense in which the gospel which he preached came

'W. D. Davies, The Setting of the Sermon on the Mount, Cambridge University Press (1964) $453 \mathrm{ff}$.

${ }^{8} \mathrm{~J}$. Wagenmann, Die Stellung des Apostels Paulus neben den Zwölf, A. Töpelmann, Giessen (1926) 34ff., cit. ap. W. D. Davies, op. cit., 454f. Davies mentions also (454) the translation 'to get information (about Jesus) from Cephas', preferred by G. D. Kilpatrick (in New Testament Essays, ed. A. J. B. Higgins, Manchester University Press (1959) 144ff.), and H. Riesenfeld's view (The Gospel Tradition and its Beginnings, Mowbray, London (195I) 19) that the purpose of ioropîoa was 'that Peter should test whether he, Paul, during his term of preparation, had really made the tradition of the words and deeds of Jesus his own'.

- In both I Cor. I 1:23 and 15:3 Paul uses the technical terms for oral transmis-

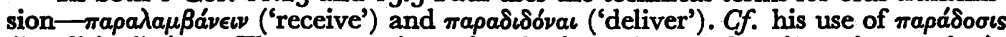
('tradition') in 2 Thess. 2:I5 (covering both spoken and written instruction); 3:6; I Cor. 11:2. For the Lord as the source of such 'tradition' ( $c f$. I Cor. I 1:23, ámò rov kvplov), see O. Cullmann, 'Kyrios as Designation for the Oral Tradition concerning Jesus (Paradosis and Kyrios)', SFT 3 (1950) 18off.; 'Scripture and Tradition', ibidem 6 (1953) I $13 \mathrm{ff}$. (with reply by J. Daniélou, 'Réponse à Oscar Cullmann', Dieu Vivant 24 (1953) ro7ff.); 'The Tradition', Eng. tr. in The Early Church, SCM Press, London (1956) $55 \mathrm{ff}$.

10 On Jerusalem as the doctrinal centre from which such traditions originate ff. B. Gerhardsson, Memory and Manuscript, 273. 
to him 'through a revelation of Jesus Christ' - 'for I did not receive it from man', 11 he emphasizes, 'nor was I taught it' (Gal. I:12) - and the sense in which it was something which he received from others. The contradiction is apparent, not real; both statements could be simultaneously true, but the apologetic or polemic requirements of the moment might cause Paul sometimes to emphasize the one side to the apparent exclusion of the other. ${ }^{12}$

If we could ask him to reconcile the two, to say how he related the gospel as revelation to the gospel as tradition, his answer might be that the core of the gospel, 'Jesus Christ the risen Lord', was revealed to him directly; it was no human testimony that had moved him to embrace this. ${ }^{13}$ True, others had maintained it in substance before he did, but it was not from them or from their witness that he came to know it for himself. On the other hand, the historical details of the teaching of Jesus, the incidents of Holy Week, the resurrection appearances and the like were related to him by those who had firsthand experience of them.

If we ask further when these things were related to Paul by those who had first-hand experience of them, no time is more likely than that fortnight spent in Jerusalem in the third year after his conversion, when he stayed with Peter and also met James. ${ }^{14}$ It was pointed out many years ago ${ }^{15}$ that the summary of resurrection appearances in I Corinthians $15: 5 \mathrm{ff}$. (excluding the final appearance to Paul himself) falls into two series, each introduced by the name of an individual, and each going back in all probability to the testimony of the man whose name introduces it. ${ }^{16}$ The two men in question, are Peter and James,

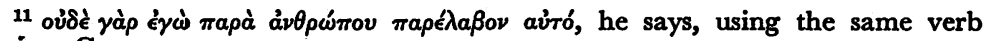
as in 1 Cor. $11: 23 ; 15: 3$.

${ }_{12}$ Cf. H. Lietzmann, Handbuch zum Neuen Testament: An die Korinther I-II,2 J. G. B. Mohr, Tübingen (1923) 58 (ad I Cor. I I :23); P. H. Menoud, 'Revelation and Tradition: The Influence of Paul's Conversion on his Theology', Interpretation 7 (r953) I 3 Iff.; B. Gerhardsson, Memory and Manuscript, 272ff., 296. J. T. Sanders, 'Paul's "Autobiographical" Statements in Galatians I-2, $7 B L$ (1966) $335 \mathrm{ff}$., cuts the knot instead of untying it by failing to take the statements of Gal. I : I I ff. with sufficient seriousness.

${ }_{18}$ Cf. Gal. 1:15f.

14 Gal. 1:r8f.

15 By A. Harnack, Sitzungsbericht der preussischen Akademie der Wissenschaften, phil.-hist. Klasse (1922) 62ff., and B. W. Bacon, The Apostolic Message, Century Co., New York (1925) I 32ff.; The Story of Jesus, Allen \& Unwin, London (1928) $304 \mathrm{ff}$.

16 B. W. Bacon (The Apostolic Message, 132ff.) saw behind the two series of appearances two traditions - a Petrine or Galilaean one, and a Jacobean or Jeru- 
and we may be sure that it was from them, on the occasion mentioned in Galatians I: $18 f f$., that Paul received his information about the resurrection appearances, together with other elements in the tradition which he held in common with those who were in Christ before him.

\section{III}

Next time he went up to Jerusalem (Gal. 2:Iff.), he was accompanied by Barnabas and by Titus, a Gentile Christian (presumably a member of the church at Antioch). On this occasion, he says, he 'went up by revelation'. The content of this 'revelation' he does not divulge; it has been variously related to the prophecy of Agabus in Acts $11: 28^{17}$ and the command of the Spirit in Acts 13:2, ${ }^{18}$ but we cannot be sure. Neither does Paul state the purpose of this visit to Jerusalem; it may, of course, have been for the precise purpose of holding those conversations with the 'pillars'19 of the Jerusalem church which he summarizes for us in the same context. He tells how he set before these leaders, James, Peter and John (and it is noteworthy that James ${ }^{20}$ now appears first in the list), the gospel which he preached among the Gentiles. He set it before them privately, it is true, but his reason for doing so at all was, he says, 'lest somehow I should be running, or had run, in vain' (Gal. 2:2).

This is an extraordinary admission, on the face of it; it looks as if Paul agrees that, in default of the approval, or at least the fellowship, of the Jerusalem leaders, his apostolic service would be fruitless. If these words are to be taken in their natural sense (as they should), ${ }^{21}$ they can only mean that, while Paul did not receive his apostolic commission from Jerusalem, he could not discharge it effectively except in association with Jerusalem. Why was this?

salem one (the latter discerned also in the Gospel according to the Hebrews). They must have been primitive traditions indeed if Paul could receive both about AD 35 .

17 E.g. by K. Lake, The Earlier Epistles of St. Paul, Rivingtons, London. (1914) 280.

${ }_{18}$ E.g. by T. W. Manson, Studies in the Gospels and Epistles, 177.

$19 \mathrm{Gk}$. orvidou. On the significance of the designation see G. K. Barrett, 'Paul and the "Pillar" Apostles', in J. N. Sevenster and W. G. van Unnik (ed.), Studia Paulina, F. Bohn, Haarlem (I953) Iff.

20. 'James the Lord's brother', as in Gal. 1:19; by the time of this visit James the son of Zebedee was dead (Acts 12:2).

21 Similar words are used in.Phil. 2:16 ('that ... I may be proud that I did not run in vain or labour in vain'); but there they refer to Paul's expectation that 'in 
One basic reason for this attitude was Paul's horror of schism. There must be no discord in the body of Christ (I Cor. 12:25); this principle is as indispensable in the Ghurch Universal as it is within any local church. If a complete cleavage came about between the Jerusalem leaders and the Gentile mission, Christ would be divided, and His cause, divided against itself, would come to grief. All the energy which Paul had devoted, and hoped to devote, to the evangelization of Gentiles would be of no avail if there was no mutual recognition between the apostolate to the circumcision and that to the uncircumcision.

However, all seemed to go well at the interview which Paul and Barnabas had with the Jerusalem leaders. The latter acknowledged that Paul and Barnabas had been called by God to evangelize Gentiles as truly as they themselves had been called to the work of Jewish evangelization, and the two sides shook hands in joint recognition of this division of labour. There is no hint of any difference with regard to the substance of the gospel. The mode of presentation might vary in accordance with the audience addressed, but the fundamental message presented was the same. Still less was there any essential difference between the two groups with regard to the person of Christ. There was no doubt a variety of overlapping Christologies in the apostolic age, ${ }^{22}$ but this was not a point at issue between Paul and the 'pillar' apostles. On the present occasion the point at issue was the demarcation of two mission fields, and this was settled amicably.

Nevertheless, it might have been said to Paul, 'So you did receive the recognition of Peter and James and the other Jerusalem leaders?' 'No', Paul would reply, 'I did not receive their recognition in the sense that my commission was previously defective without it; they recognized that I had already been called to this ministry, but they did not in any sense confer on me the right to exercise it.'

And no doubt this was true; Paul and Barnabas had already

the day of Christ' his apostolic career will be assessed by the quality of his converts and to his hope that he will have no reason to be ashamed of them then. He is prepared for his apostolic service to be judged by the quality of his converts before the divine tribunal; he will not allow either the quality of his converts or his own apostolic service to abide the judgment of any human tribunal, not even that of the apostles and elders in Jerusalem.

${ }^{29} C f$. the 'Lord and Christ' of Acts $2: 36$, the 'Servant' of Acts $3: 13$, the 'Prophet' of Acts $3: 22 f$., the 'Son of man' of Acts 7:56, the 'Son of God' of Acts 9:20, etc. overlapping but not inconsistent 'Christologies'. 
been energetically engaged in Gentile evangelization, no matter how early we date this second Jerusalem visit. ${ }^{23}$ Yet the distinction was a fine one, and the situation could easily have been misrepresented by anyone who did not care, or did not wish, to observe the distinction accurately. Perhaps the Jerusalem 'pillars' themselves would not have given precisely the same account of the matter as Paul does; this is not an unexampled state of affairs where two groups of honest men receive and convey different impressions of one and the same set of circumstances because they view the circumstances with different presuppositions.

The only condition which was imposed on us at that time, says Paul (if condition it can be called), was that we should go on remembering 'the poor' $;^{24}$ but this (he adds) was something that I myself had already made a special point of doing. ${ }^{25} \mathrm{We}$ can scarcely exclude a reference here to the famine-relief visit of Acts I I:30 (whether that visit be identified with the visit of Gal. 2:I or not). And how seriously Paul continued to take this responsibility may be gauged from the importance which he attached to the 'collection for the saints' which we find him organizing in the churches of the Aegean world some years later. We may indeed suspect that what was from Paul's point of view a voluntary act of charity or a purely moral obligation was in the eyes of the Jerusalem church a tribute due, analogous perhaps to the tax which Jews throughout the world contributed annually to the maintenance of the Jerusalem temple and its services. ${ }^{26}$

To Paul, however, the collection also provided a welcome opportunity of strengthening the bonds of fellowship between the Jerusalem church and the Gentile mission. Since his

is My own inclination is to identify it with the famine-relief visit of Acts 1 I:30 and so to date it about $\mathrm{AD} 46$. This involves making Paul's conversion the terminus $a$ quo of the 'fourteen years' of Gal. 2:I as of the 'three years' of Gal. I:18.

2s On 'the poor' as a designation for the Jerusalem church see K. Holl, Gesammelte Aufsätze 2, J. C. B. Mohr, Tübingen (1928) $58 \mathrm{ff}$.

${ }^{25}$ The tenses of Gal. 2:10 are important: "they begged us "to go on remember-




with the fact that Paul had actually just brought alms to Jerusalem: it is almost a pluperfect', C. W. Emmet in F. J. F. Jackson and K. Lake (ed.), The Beginnings of Christianity 2, Macmillan, London (I922) 279).

${ }^{26}$ But it is hardly likely that he was regarded as an official 'apostle of Zion' (seliah siyyon) charged with the collection of money for the holy community at Jerusalem; cf. J. Klausner, From Fesus to Paul, Eng. tr., Allen \& Unwin, London (1944) 364f.; H. J. Schoeps, Paul, Eng. tr., Lutterworth Press, London (196r) 68f. 
converts had received spiritual blessings from Jerusalem (in the sense that the gospel which brought them salvation began at Jerusalem), it would be a fitting token of gratitude on their part to send to Jerusalem material aid which was sorely needed there. ${ }^{27}$ The Jerusalem church for its part, he hoped, would experience a corresponding sense of gratitude on the receipt of this gift and would thus be stimulated to think with affection of the Gentile churches and to pray for them with redoubled fervour. ${ }^{28}$ If delegates from the various Gentile churches actually accompanied Paul to Jerusalem, carrying their churches' contributions, ${ }^{29}$ this would not only be a guarantee of honest dealing should any questions be asked about the administration of the money ${ }^{30}$ but would further promote a sense of solidarity between Jerusalem and the Gentile mission. For Paul to hand over a gift from his Gentile converts would be one thing; for some of those Gentile converts to appear in person and hand over the gifts from their own churches would be much more telling. In the event, unfortunately, it was the presence in Jerusalem of those Gentiles-or at least of one of them-that precipitated the riot which led to Paul's arrest, imprisonment and trial. But to this we shall return. ${ }^{31}$

IV

To go back to Paul and Barnabas's interview with the Jerusalem leaders described in Galatians 2:I-I0, the upshot was that the two parties' respective spheres of service were delimited. Paul thenceforth made it a point of principle not to intrude into anyone else's sphere, not to 'build on another man's foundation' (Rom. 15:20). But he expected a corresponding sensitivity from Jerusalem, and repeatedly found that it was not forthcoming. Whether the 'pillars' themselves had any direct responsibility in this matter may be doubted; what is clear is that others in

27 Rom. 1 5:27.

282 Cor. 9:1 1-14.

29 I Cor. 16:3f.; of. Acts $20: 4$.

302 Cor. 8:20ff.

${ }^{81}$ Acts 21 :29. In Acts 18:22 brief mention is made of a visit paid by Paul between his Corinthian and Ephesian ministries to Palestine-and to Jerusalem, for 'the church' to which he 'went up' from Caesarea can only have been the Jerusalem church. One reason for this visit is suggested in the context-the Nazirite vow of Acts 18:18, which may have required a final discharge in the Jerusalem temple after his hair was cut in Cenchreae-but it is open to surmise that on this occasion too he had remembered 'the poor'; hence the urgency of his departure for Jerusalem from Ephesus despite the pressing invitation he received to 'stay for a longer period' in the latter place (Acts 18:20). 
their name had no scruples about invading Paul's missionary sphere. ${ }^{32}$

The contretemps with Peter at Antioch which Paul describes in Galatians 2:I Iff. was in a different case. It was not Peter's presence at Antioch, but his sudden withdrawal from tablefellowship with Gentile Ghristians that Paul took exception to. The real trouble-makers were those visitors ${ }^{33}$ 'from James' who intimidated Peter into his ill-conceived action. It has been suggested with some plausibility that a message was brought to Peter from James in some such terms as these: 'News has come to Jerusalem that you are eating Gentile food at Gentile tables, and this is causing great scandal to many devout brethren besides laying us open to serious criticism from the Scribes and Pharisees. Pray discontinue this practice, which will surely do great harm to our work among our fellow-countrymen. ${ }^{34}$

I am disposed to believe, further, that this occasion provides the setting for Paul's words in Galatians 2:4f., where, after remarking that when he and Barnabas took Titus to Jerusalem no pressure was put on Titus to be circumcised, Greek though he was, he goes on: 'The question of circumcision was not raised until later, when it was brought up by some pseudoChristians who infiltrated into our position to spy out our Christian liberty. ${ }^{35}$ It was brought up not only at Antioch but in the churches of Galatia too, but it was settled by the decree of the Council of Jerusalem. This decree did not settle all the points at issue between the Gentile mission and Jerusalem, and perhaps raised some points which were to cause further tension as time went on, but it does not appear that the demand for the circumcision of Gentile converts was pressed with any colourable claim to authority from Jerusalem after the decisive meeting of the Gouncil. ${ }^{36}$ The earlier form of judaizing activity

82 This is the implication of his complaint in 2 Cor. 10:12-18, where he insists on the kavóv (here 'sphere of activity') which God has allotted to him and refuses to

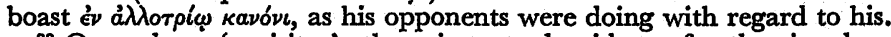

${ }^{33}$ Or perhaps ' $a$ visitor'; there is textual evidence for the singular Tiva and $\eta \lambda \theta \in v$ instead of the plural tivas and $\eta \lambda \theta o v$ in Gal. 2:12.

34 T. W. Manson, Studies in the Gospels and Epistles, 181.

${ }^{35} C f$. T. W. Manson, op. cit., $175 \mathrm{f}$. This is much more probable than that Titus actually was circumcised during the Jerusalem visit, whether with Paul's consent and even by his act (F. C. Burkitt, Christian Beginnings, University of London Press, (1924) 1 18) or on his own initiative and without Paul's consent (A. D. Nock, St. Paul, Thornton Butterworth, London (1938) rog).

${ }_{88}$ It may be Jews pure and simple, and not Jewish Christians, who are later

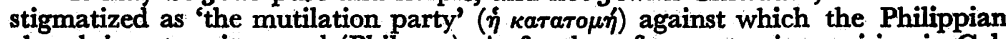
church is put on its guard (Phil. 3:2). As for the reference to circumcision in Col. 
in Paul's mission field, which invoked the name of James and insisted on circumcision, gave way to a later form, which invoked rather the name of Peter and did not insist on circumcision. The former is reflected in Galatians, the latter in the Corinthian correspondence. ${ }^{37}$

From what has just been said, it will be seen that the trouble which broke out in the churches of Galatia and called forth the Epistle to the Galatians is dated before the Council of Jerusalem of Acts 15. For a number of reasons it seems to me impossible to identify the meeting of Galatians 2:I-10 with that of Acts I5. On the former occasion, Paul implies, the question of circumcision was not raised; on the latter occasion, it was the central question at issue. The necessity of imposing it on Gentile converts was strongly urged by one party in the Jerusalem church, but the decision of the conference-a decision reached the more readily because of James's statesmanshipwas that it should not be imposed. The role filled by James has been too often undervalued in apostolic history; Paul himself, throughout the variegated sphere of his Gentile ministry, had no more delicate situation to hold in hand than James had in Jerusalem. Even after the dispersion of the Hellenists which followed the death of Stephen the membership of the Jerusalem church remained highly diversified; there was no one 'Jerusalem line'. ${ }^{38}$

Formally the Council of Jerusalem was a conference between the leaders of the church of that city and representatives from the church of Antioch, and to Paul at least it was nothing more. But many in Jerusalem took it for granted that the Council had laid down binding rules for Gentile Christianity which would be valid for all time to come; and in fact many Gentile churches did continue for centuries to accept this point of view. ${ }^{39}$ Not so Paul, for whom the letter embodying the

2: 11 , this may imply that circumcision played a part in the 'Colossian heresy', but that 'heresy' did not emanate from Jerusalem, but was a product of Phrygian syncretism.

${ }^{87}$ For these two forms of judaizing activity see T. W. Manson, Studies in the Gospels and Epistles, 197ff.; H. J. Schoeps, Paul, 66; C. K. Barrett, 'Christianity at Corinth', BFRL 46 (1963-64) 273ff.; also his 'Cephas and Corinth' in O. Betz, M. Hengel and P. Schmidt (ed.), Abraham unser Vater, E. J. Brill, Leiden (1963) Iff.

38 Most of the Hellenists were dispersed, but not all: 'Mnason of Cyprus', a disciple from the beginning (ảpxaîs $\mu a \theta \eta r^{\prime} s$ ), was available to be host to Paul's Gentile companions in $\mathrm{AD} 57$ (Acts $21: 16$ ).

30 The observance of the decrees is attested for proconsular Asia later in the 
Council's findings, addressed to 'the brethren who are of the Gentiles in Antioch and Syria and Cilicia' (Acts 15:23), dealt with a specific situation that had arisen in the church of Antioch and its daughter-churches, and did not necessarily carry any wider authority.

The consequent disagreement about the scope of the Council's ruling appears not in regard to circumcision (which henceforth was not such a serious issue) but in regard to the codicil annexed to the ruling-in particular to those clauses which required abstention from the eating of flesh with the blood and from the eating of food sacrificed to idols. ${ }^{40}$

In a mixed church of Jewish and Gentile antecedents a modus vivendi of this kind was necessary if table-fellowship was not to be rendered quite impracticable; and a practical man like Paul would have been the first to acknowledge this. In several of his letters he urges insistently that Christians with robust consciences should be prepared voluntarily to forgo some of their liberty in the interests of their weaker brethren, as he himself did. ${ }^{41}$ But any suggestion of imposing such a restriction of liberty as a binding rule, whether the imposing authority was the church of Jerusalem or any other person or persons, Paul resolutely opposed.

The Antiochene delegates gladly accepted the Council's ruling with its codicil as a modus vivendi for their own church and her daughter-churches. ${ }^{42}$ But later attempts to extend its validity over Gentile churches subsequently founded in Paul's mission field led to fresh trouble.

\section{$\mathrm{V}$}

Those who, in James's name, had tried to impose on the

century (Rev. 2:14, 20), for Gaul in AD 177 (Eusebius, Hist. Eccl. v. 1. 26), for North Africa later in the second century (Tertullian, Apology 9), while in England towards the end of the ninth century they were incorporated in King Alfred's law-code.

${ }_{40}$ Acts 15:20, 29; $21: 25$. On the text see P. H. Menoud, 'The Western Text and the Theology of Acts', Studiorum Novi Testamenti Societas, Bulletin 2 (195I) 19ff., especially 22ff.; C. S. C. Williams, Alterations to the Text of the Gospels and Acts; Blackwell, Oxford (195I) $72 \mathrm{ff}$.

4 Cf. especially Rom. 14:1-15:6; also I Cor. 8:7-13.

42 Her daughter-churches in this case, according to Acts 16:4, included the recently planted churches of South Galatia. But see A. S. Geyser, 'Paul, the Apostolic Decree and the Liberals in Corinth', in J. N. Sevenster and W. C. van Unnik (ed.), Studia Paulina, 124ff., especially $136 \mathrm{ff}$., for arguments in favour of

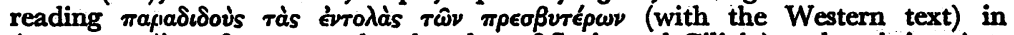
Acts I 5:4I (in reference to the churches of Syria and Cilicia) and omitting Acts 16:4 as a duplicate. 
Galatian churches a legalism which included circumcision were charged by Paul with preaching 'a different gospel' which was a perversion of the gospel of Christ (Gal. 1:6f.). Those who, apparently in Peter's name, later tried to impose on the Corinthian church a modified legalism which did not include circumcision were similarly charged with bringing 'another Jesus than the one we preached, .. a different spirit from the one you received, .... a different gospel from the one you accepted' (2 Cor. I I:4).43 But at an earlier stage of his dealings with the Corinthian church Paul makes it plain that he regards the Jerusalem apostles, Peter and James included, as proclaiming the same fundamental evangelic facts as he did himself: 'whether then it was I or they, so we preach and so you believed' (I Cor. I5:I I). If Paul at Antioch charged Peter with playacting (نं was that Peter was in basic agreement with Paul, although for reasons of expediency he was for the moment playing a part which did not correspond to his own convictions in the matter.

It is clear, however, that, within a quarter of a century from the death and resurrection of Christ, at least two rival versions of the gospel ${ }^{44}$ were in circulation. It is equally clear, on Paul's testimony, that the gospel preached by the Twelve was essentially the gospel which he himself preached. When he speaks of another gospel which he does not recognize as a gospel at all, he does not accuse the Twelve of preaching it. What then was it which, in his view, preserved the essence of the gospel, and what was it that perverted it?

Why, for example, does he describe the teaching that was

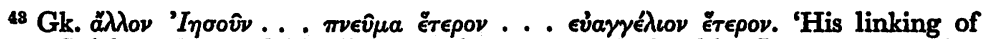
Jesus, Spirit and gospel highlights an important relationship. It exposes the indissoluble interdependence between these three concepts. The Spirit does not work separately from a proper assessment of the significance of Jesus, nor is the gospel still the gospel when the Spirit is suppressed' (G. H. Pinnock, The Concept of Spirit in the Epistles of Paul, unpublished Ph.D. Thesis, University of Manchester (1963) 92). Even if, as a number of scholars hold, these people presented a gnosticizing interpretation of Jesus ( $c f$. H. J. Schoeps, Paul, 20; W. Schmithals, Die Gnosis in Korinth ${ }^{2}$, Vandenhoeck \& Ruprecht, Göttingen (1965) 124ff; D. Georgi, Die Gegner des Paulus im 2. Korintherbrief, Neukirchen Verlag, Neukirchen-Vluyn (1964) 284f.), a Jesus whose saving work was to be appropriated in any degree by legal works rather than by faith would be in Paul's eyes 'another Jesus' than the one he proclaimed.

4 This form of words seems preferable to speaking of 'two rival kerygmata' (S. G. F. Brandon, Modern Churchman, N.S., 5 (1961-62) 225); the difference may have had to do with the interpretation of a common kerygma rather than with the kerygmatic data themselves. 
being accepted in the churches of Galatia as 'another gospel which is not another'45 (Gal. r:6f.) ? It was because this teaching added as a proper ingredient of the gospel something that had nothing to do with it, something that (as Paul saw it) denied its very basis, that he stigmatized it as no gospel at all, rightly so called. The age of the Messiah had superseded the age of the Torah; to reimpose the Torah, even partially, was tantamount to proclaiming that the age of the Messiah had not yet arrived, and that Jesus' messianic claim was accordingly. invalid. 46

Again, what of the 'different gospel' which, at a later date, some visitors brought to Corinth? It shared at least one subsidiary feature with the false gospel which Paul attacks in Galatians, in that its preachers minimized Paul's title to be recognized as an apostle; but this was not what invalidated. their message in his eyes. There is something to be said for relating it to an attempt by the party which claimed Peter's authority to impose the conditions of the codicil to the Jerusalem decree-more particularly the food-regulations-on the church of Corinth and perhaps other Pauline churches. ${ }^{47}$

Paul, as has been indicated, may well enough have accepted: these conditions to facilitate social relations between Jews and Gentiles in the church of Antioch and her daughter-churches. But he did not regard them as bearing universal and permanent validity. If it is asked, for instance, why he does not appeal to the Jerusalem decree when he is invited by the Corinthians to give a ruling on the question of food offered to idols, the answer is that he could not, because he did not agree with the decree on this score-even if he agreed with it at the time it was issued, he no longer agreed with it when he wrote I Corinthians. The decree forbade absolutely the eating of food offered to idols; to Paul's way of thinking-and this illustrates how thorough-going his Christian libertarianism was-there was nothing harmful in such food. It might be freely eaten provided the eater took it with a clear conscience and provided his example did no harm to someone else's conscience. ${ }^{48}$ With

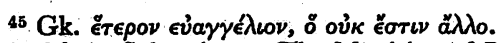

${ }^{46} \mathrm{Cf}$. A. Schweitzer, The Mysticism of Paul the Apostle, Eng. tr., A. \& C. Black, London (I93I) 186; L. Baeck, 'The Faith of Paul', $77 S$ 3 (1952) 93ff.; H. J. Schoeps, Paul 42, I68ff.; W. D. Davies, The Setting of the Sermon on the Mount, $180 f f ., 446 \mathrm{ff}$.

4 Off. C. K. Barrett, 'Things Sacrificed to. Idols', NTS I I (1964-65) 138ff.

48 I Cor. 8:7ff.; Rom. 14: r 3 ff. 
these provisos, a Christian might say grace over $\varepsilon i \delta \omega \lambda \hat{\theta} \theta u \tau \alpha$ and preserve complete peace of mind as he ate. ${ }^{49}$ Food in itself was religiously neutral, as indeed circumcision also was; $;^{50}$ it was when people tried to impose rules and regulations in regard to the one or the other that the gospel was compromised. And the attempt to impose food-laws as matters of evangelical obligation may have threatened the purity of the gospel at Corinth as the attempt to impose circumcision did in Galatia. If one or the other were held to be a necessary condition of salvation or of church fellowship, the principle of righteousness by grace through faith was nullified.

\section{VI}

But for all Paul's assertion of freedom from rules and regulations, he was compelled to conduct his warfare on two fronts. Things like food and circumcision might be religiously neutral, but personal relations were not. Liberty might be asserted to the prejudice of that love which, because it ever seeks to help and not to harm another, is 'the fulfilling of the law' (Rom. I3:10). Over against those rivals of Paul who wished to impose various legal restrictions on his converts' faith, there were some of his converts who played into the hands of the legalists by casting off ethical restraint and asserting a form of liberty which was indistinguishable from licence. These people, 'whose god is their belly and who glory in their shame' (Phil. 3:19), Paul denounces as enemies of the cross of Christ, bound for perdition. ${ }^{51}$ The path between legal bondage and lawless licence must at times have seemed to be a very narrow one!

It was not because legalists and libertines alike opposed or denigrated Paul that he denounced them, but because they perverted the gospel. Some of his opponents did not appear to him to pervert the gospel, and although he did not appreciate their opposition, he refers to them in quite a different vein. Telling his Philippian friends of his current circumstances, he says (Phil. 1:12-18):

What has happened to me has really served to advance

49 . Cor. 10:30; Rom. 14:6.

so r Cor. 7:19; Gal. 5:6; 6:1 5 ; so Paul's circumcision of Timothy (Acts $16: 3$ ) was a minor operation performed for a practical purpose and not by way of legal obligation, and therefore was religiously neutral.

51 Such libertinism was specially manifest in a section of the Corinthian church, e.g. in those who regarded the illicit union of 1 Cor. 5:1 as a fine assertion of evangelical freedom (I Cor. 5:2); $c f$. I Cor. 6:12ff. 
the gospel. It has become known throughout the whole praetorium, and to all the rest, that my imprisonment is for Christ's sake; and most of the brethren have been made confident in the Lord because of my imprisonment, and are much more bold to speak the word of God without fear. Some indeed preach Christ from envy and rivalry, but others from good will. The latter do it out of love, for they know that I am posted here for the defence of the gospel; the former preach Christ out of partisanship, not from sincere motives but imagining that their doing so will add to the affliction of my imprisonment. What then? Just this: one way or the other, whether in pretence or in truth, Christ is preached, and in that I rejoice.

Why did Paul denounce some of his opponents as perverters of the true gospel, as preachers of a message that was no gospel at all, while he aquiesced, or indeed exulted, in the missionary activity of other opponents, even if they only did it to annoy? The answer lies not in their personal attitude to him or in their evaluation of his apostolic claims, but in the message they preached. If the message was false, then let the preacher be anathema, even if he were Paul himself or an angel from heaven. If the message was true, then let God be thanked, even if the preacher had no worthier motive than rubbing salt into Paul's wounds. Luther was never more truly a follower of Paul than when he said: 'What does not teach Christ is not apostolic, even if Peter and Paul teach it. Contrariwise, what does preach Christ would be apostolic, even if Judas, Annas, Pilate or Herod did it.'52

The gospel according to Paul ${ }^{53}$ had distinctive emphases which marked it off from the presentation of the same essential gospel by other New Testament preachers. But these distinctive emphases were bound up with Paul's Gentile apostolate and with the 'mystery' which Paul had been specially commissioned to make known. ${ }^{54}$ No blame accordingly attached to those who had not been entrusted with this 'mystery', and therefore could not communicate it. It was not for falling short in this respect that Paul denounced preachers of 'another gospel'. Again, there is no evidence that that 'other gospel' laid

s2 Preface to Epistle of 7ames, Weimar edition, 7, 384, 385 .

68 'My gospel', as he calls it in Rom. 2:16; 16:25.

s4 Rom. I6:25; Col. I:26ff.; Eph. 3:3ff. 
more stress on the 'historical Jesus' than Paul's own preaching did. If 'Jesus Christ crucified' was publicly portrayed in Paul's preaching to the Galatians (Gal. 3:I), ${ }^{55}$ a vivid account of at least one phase of the historical Jesus is implied. Paul's words about not knowing 'Christ after the flesh' in 2 Corinthians 5:16 have frequently been adduced as evidence that he was not interested in the facts of Jesus' earthly life, ${ }^{56}$ but this is mistaken exegesis of the passage, which is well rendered as follows in the New English Bible: 'With us therefore worldly standards have ceased to count in our estimate of any man; even if once they counted in our understanding of Christ, they do so now no longer.' Paul is not here contrasting his own knowledge of Christ ( $\varkappa \alpha \tau \dot{\alpha} \pi \nu \varepsilon \tilde{\mu} \mu \alpha$, presumably) with that which had been enjoyed by the Twelve (as though it were merely $x \alpha \tau \dot{\alpha} \sigma \alpha \dot{\rho} x \alpha)$; he is contrasting his own present knowledge of Christ with his earlier attitude to Him before his conversion, as is indicated by the words that immediately follow: 'When anyone is united to Christ, there is a new creation; the old order has gone, and a new order has already begun' (2 Cor. 5:17).

\section{VII}

This has brought us back to Paul's relations with the Twelve. We have considered the light cast on these relations by the autobiographical narrative in Galatians $1: 18-2: 14$ and the outline of the kerygma and resurrection appearances in I Corinthians I5:I-II. When, earlier in I Corinthians, Paul deprecates the party spirit which is rife in the Corinthian church, ${ }^{57}$ it is not because he disapproves of the men who are put forward as his rivals; he disapproves of a 'Paul party' as much as of any other. What he deplores is the self-impoverishment of those Christians who avail themselves of only one of their Lord's servants when all His servants are at their disposal: 'Paul or Apollos or Cephas ... all are yours' (I Cor. 3:22).

But what of the terms in which Paul vindicates his apostleship in 2 Corinthians ro-1 3 against those whom he ironically

${ }^{35} C f$. I Cor. $2: 2$.

so So R. Bultmann, Glauben und Verstehen 1, J. C. B. Mohr, Tübingen (196r) 208; H. J. Schoeps, Paul, 57, 72, 79; $f f$. the discussion in W. Schmithals, Die Gnosis in Korinth ${ }^{2}, 286 \mathrm{ff}$., where, after a review of various interpretations, the words are explained as a gnosticizing gloss!

s7 I Cor. 1:12ff. 


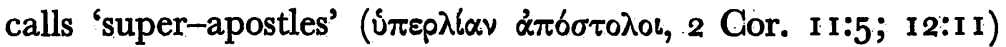
and those whom he condemns unsparingly as 'false apostles ( $\psi \varepsilon u \delta \alpha \pi \delta ́ \sigma \tau 0 \lambda \circ \iota)$, deceitful workers, masquerading as apostles of Christ' (2 Cor. II:13)?

The 'super-apostles' are probably the Jerusalem apostles (the Twelve and James) whose apostleship was held forth by Paul's critics as a pre-eminent apostleship, far superior to Paul's (if indeed he had any right to be called an apostle at all.) ${ }^{58}$ But Paul appeals to the Corinthians' personal experience of his apostolic work, so as to compel them to admit, with him, that 'I came not a whit behind those super-apostles' (2 Cor. I I:5).

As for the false or counterfeit apostles, the evidence is against identifying them with members of the Twelve or James. ${ }^{59}$ In all Paul's unambiguous references to the Twelve or James, he takes their apostolic status for granted, insisting only that his own apostleship is as genuine as theirs.

When he found it necessary to vindicate his apostleship to the Corinthian church at an earlier date, he appealed not only to the fact that they were the 'seal' of his apostleship (I Cor. 9:2) but primarily to the fact that he had 'seen Jesus our Lord' (I Cor. 9:I). It need scarcely be argued that his claim to have seen Jesus is a claim to have seen Him in resurrection; but by the same token he bears witness later in I Corinthians to the genuineness of the apostleship of the Twelve and James by rehearsing the evidence that they too had seen Jesus in resurrection. It was then, in fact, that they received their definitive commission, just as Paul received his when he in his turn, albeit belatedly, saw the risen Christ (I Cor. :5:5-8).

If the counterfeit apostles had no place in their scheme of things for Paul, they may have had very little even for the Twelve, whom they probably regarded in their hearts as compromisers, even if it was expedient to claim the backing of their authority. If Paul can recognize (as he does) true apostles outside the ranks of the Twelve and himself, ${ }^{60}$ there is no particular

58 So E. Käsemann, 'Die Legitimität des Apostels: eine Untersuchung zu 2 Kor. 10-13', ZNTW 4I (1942) 33ff.; H. J. Schoeps, Paul, 73, 75.

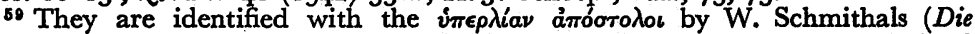
Gnosis in Korinth ${ }^{2}, 267$ ) and D. Georgi (Die Gegner des Paulus im 2. Korintherbrief, $39 \mathrm{ff}$.), who, however, regard them as heralds of gnosticism, having nothing to do with the Twelve or James.

${ }^{80} \mathrm{Cf}$. I Cor. 4:9; 9:5; Gal. 1:19; see also K. H. Rengstorf, s.v. ámóorodos, in G. Kittel (ed.), Theological Dictionary of the New Testament 1, Eng. tr., Eerdmans, Grand Rapids (1964) 407ff., especially $430 f f$. 
reason why his 'false apostles' should be sought within these ranks.

If we look for the provenience of these 'false apostles', we can hardly fail to locate it in Jerusalem and Judaea. ${ }^{61}$ Apollos of Alexandria and his school cannot be thought of in this connection. Paul deprecates the use of Apollos's name as 'a party slogan, just as he deprecates the similar use of his own name $;^{62}$ but the friendly language in which he writes of Apollos ${ }^{63}$ makes it clear that even if Apollos's gospel was originally defective (as Luke assures us it was), ${ }^{64}$ yet in the form in which he preached it in Gorinth it was not substantially a different gospel from Paul's.

It is easier to say what the 'different gospel' of 2 Corinthians I I:4 was not than to suggest what it precisely was. Had it been some form of charismatic gnosticism, Paul's language would have indicated that more clearly, as the argument in the Epistle to the Colossians helps us to reconstruct the outlines of the 'Colossian heresy'. But Paul's language does not indicate clearly wherein this 'different gospel' consisted; and this is probably due not only to the fact that his readers were acquainted with it and so did not require to have it described to them, but also to the fact that Paul was embarrassed by the necessity of exposing the hollow pretensions of the 'false apostles' who brought it without appearing to criticize the Jerusalem apostles whose authority they claimed. ${ }^{65}$ It may be concluded, however, that among Paul's reasons for stigmatizing his opponents' message as a 'different gospel' were its exaltation of human achievement in place of the grace of God and its addition of other terms of salvation to the principle of faith which God had declared acceptable. ${ }^{66}$

The late Johannes Munck's thesis that the opposition to Paul at Corinth, like judaizing and other 'deviations' elsewhere in

${ }^{61}$ Their implied claim to be 'Hebrews' (2 Cor. I1:22) suggests that they were not Jews of the Dispersion.

${ }^{62}$ I Cor. 3:4-6.

os I Cor. 4:6; $16: 12$.

${ }^{64}$ Acts 18:24ff.

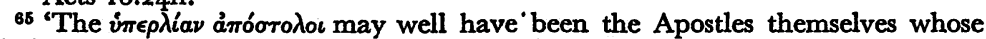


Eng. tr., Williams \& Norgate, London (1876) 277). 'When he speaks ... of "chief apostles" he is referring especially to the part which certain individuals thrust upon them and he avoids involving them personally in his attacks' (M. Goguel, The Primitive Church, Eng. tr., Allen \& Unwin, London (1964) 48).

${ }^{B 6} C f$. F. F. Bruce, 'When is a Gospel not a Gospel?', BJRL 45 (1962-63) 3 r $9 \mathrm{ff}$., especially $33^{8 f}$. 
his mission field, arose solely among his own Gentile converts ${ }^{67}$ will hardly stand up to close investigation. In his anti-Tübingen zeal he leant too far in the opposite direction to the position which he attacked. According to him, the only difference between Paul and Jerusalem lay in their varying conceptions of the relative order in which Jewish and Gentile evangelization should be prosecuted, the Jerusalem leaders appealing to Old Testament prophecy in support of their view that the conversion of Israel would result in the evangelization and conversion of the Gentiles, while Paul saw the conversion of the Gentiles as preceding the large-scale conversion of Israel. ${ }^{68}$ But precisely here Munck has pointed to a further reason for the importance which Paul attached to the fullest fellowship with Jerusalem.

\section{VIII}

Paul himself had not been called to evangelize Jews, but indirectly he expected that his ministry to Gentiles would promote the salvation of Israel. Indeed he says plainly that for this reason he 'magnified his office' because he hoped by his Gentile evangelization to make his fellow-Israelites envious. ${ }^{69}$ So far as the offer of the gospel was concerned, the order might be 'to the Jew first and also to the Greek' ${ }^{70}$ so far as its acceptance was concerned, the order was to be 'by the Greek first and also by the Jew'- by the Jew through envy at seeing so many Gentiles appropriating those gospel blessings which were the Jews' natural heritage as descendants of Abraham. The largescale turning of Jews to Christ would, as Paul saw it, be the last stage in the divine programme for the current age. When the full number of Gentiles had been gathered in, so all Israel would be saved, its temporary blindness removed: ${ }^{71}$ Paul sees in this consummation the fulfilment of the psalmist's prayer, ' $O$ that salvation for Israel would come out of Zion!' (Ps. 14:7; $53: 6)$. By combining this prayer with the Septuagint reading of

${ }^{87} \mathrm{~J}$. Munck, Paul and the Salvation of Mankind, Eng. tr., SGM Press, London (1959) 140ff., I $7 \mathrm{r}$ ff., where it is maintained that the opposition to Paul at Corinth was not judaizing, as it was in Galatia, albeit as an indigenous Gentile-Christian development (op. cit., 87ff.).

${ }^{68} O p$. cit., 255ff., 276; of. his Christus und Israel, Universitetsforlaget, Aarhus, and Munksgaard, Copenhagen (1956) $92 \mathrm{ff}$.

69 Rom. I1:13f.

${ }^{70}$ Rom. 1:16 (cf. 2:9f.).

71 Rom. I1:25f. 
Isaiah 59:20, 'There shall come a deliverer for Zion's sake 72 and he shall turn away ungodliness from Jacob', ${ }^{73}$ Paul appears to make this final salvation of Israel coincide with the parousia. His own work, then, both in its direct effect among the Gentiles and in its indirect implication for the Jews, is a preparation for this momentous event. Paul is thus clearly set forth as a figure of eschatological significance. ${ }^{74}$

In this light we can see even more significance in the collection for Jerusalem. Not only was this designed to be a bond of fellowship between the Gentile mission and the mother church, as Paul's converts acknowledged with their material help their indebtedness to Jerusalem for the spiritual blessing which had come to them from there; it was fraught with eschatological meaning. This may be seen in Paul's reference to the collection in Romans I 5:25-3 I, following immediately on his reflections on the Gentile mission in the preceding verses (15-24). ${ }^{75}$ The collection is the 'fruit' of the Aegean phase of his mission which has just been completed, and his service thus far is to be 'sealed' by the presentation of this fruit in Jerusalem. In a sense the money collected might be called 'the offering of the Gentiles', but it is not 'the offering of the Gentiles' mentioned by Paul in verse 16 ; it is but an outward and visible sign of that offering. When Paul speaks of the $\pi \rho \circ \sigma \varphi \circ \rho \dot{\alpha} \tau \tilde{\omega} \nu \dot{\varepsilon}^{2} \theta \nu \tilde{\omega} \nu$, we are to understand $\tau \tilde{\omega} \nu \varepsilon \dot{\theta} \theta \tilde{\omega} \nu$ as objective (or appositional) genitive, not subjective; the Gentile believers are the offering which Paul himself is presenting to God, thus discharging his 'priestly



In Old Testament prophecy the future ingathering of the Jews from the lands of their dispersion is sometimes portrayed in terms of the Gentiles' escorting them to Jerusalem as an 'offering (Heb. minhâ) to Yahweh' (Is. 66:20; ff. Zp. 3:10). But Paul has something more magnificent and surprising in

${ }_{72} \mathrm{Gk}$. Eี

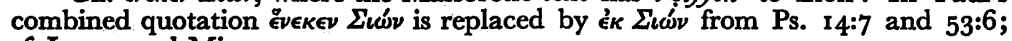
cf. Is. $2: 3$ and Mi. $4: 2$.

${ }_{73}$ The words that follow, 'and this will be my covenant with them, when I take away their sins', represent a combination of Is. 59:2 1a with Is. 27:9 and Je. $31: 33 f$.

${ }_{74} \mathrm{~J}$. Munck, Paul and the Salvation of Mankind, $4 \mathrm{rff}$--although the associated argument that Paul is the 'restrainer' of 2 Thess. 2:6f. (following $O$. Cullmann, 'Le caractère eschatologique du devoir missionnaire et de la conscience apostolique de S. Paul', Revue d'Histoire et de Philosophie Religieuses 16 (1936) 210ff.) is less convincing.

${ }_{76}$ On this see K. F. Nickle, The Collection: A Study in Paul's Strategy (SGM Press, London (1966)). 
mind: for him the people of God embrace Gentiles on an equal footing with Jews, and since the ingathering of the Gentiles is his special responsibility the offering which he will present to the Lord consists not merely of Jews from the Gentile lands but of Gentiles themselves.

Nor does he think of presenting this offering to the Lord anywhere else than in Jerusalem. He could not take all his Gentile converts with him to Jerusalem, but he could take some representatives, and we may surmise that those who are named as accompanying him in Acts 20:4 went to Jerusalem in this capacity as well as to take their respective churches' contributions. All those Gentile Christians were evidently welcomed by the leaders of the mother church on their arrival: 'When we had come to Jerusalem', says Luke, 'the brethren received us gladly. On the following day Paul went in with us to James; and all the elders were present' (Acts 2I:I 7f.). Luke, for reasons of his own, ${ }^{76}$ says nothing of their connection with the 'alms and offerings' which Paul, later in his narrative, is said to have brought to Jerusalem (Acts 24:1 7); but his silence in this respect gives us no ground for refusing to use what he does tell us to illuminate Paul's account. Moreover, Paul may have the more readily accepted the suggestion of James and his fellow-elders that he should associate himself with some believing Nazirites who were about to take part in a purificatory ceremony in the temple because that would give him an opportunity of rendering an account of his stewardship in the very place where, over twenty years before, the Lord appeared to him in a vision and sent him 'far away to the Gentiles' (Acts 22:2I). His converts could not accompany him there, in spite of the charge that he had taken one of them into the temple with him, but there in spirit he could fulfil 'the offering of the Gentiles' who had believed through his ministry hitherto, and seek grace and strength for the remaining phase of his ministry. Such an interpretation of Paul's conduct is not invalidated by the unhappy sequel to his temple visit. ${ }^{77}$

$\mathrm{He}$ may indeed have hoped that on a later occasion, when

${ }^{76}$ Perhaps for apologetic reasons arising out of the charge on which Paul had ultimately to appear before Caesar.

${ }_{77}$ Paul's earlier Nazirite vow, undertaken on his own behalf (Acts 18:18), has been mentioned above (p. I I, n. 3I). His acceptance of the elders' suggestion on this occasion, whatever may be thought of its wisdom, was neither humiliating nor compromising, but consistent with Paul's policy stated in I Cor. 9:20. 
his contemplated evangelization of Spain ${ }^{78}$ had been completed in its turn, he might visit the temple again and render a further account of his stewardship, perhaps the final account. This, as we know, was not to be, but Paul did not foresee the future at the moment of his entry into the temple. Nevertheless, there is ground for believing that Jerusalem filled an important role in Paul's eschatological thinking. Not only was the Gentile mission to be, in the purpose of God, the precursor of Israel's salvation; Jerusalem was to be the place from which this crowning phase of the salvation of mankind would be displayed. To allow a breach with Jerusalem, then, would seriously handicap the accomplishment of God's saving purpose, which was making use of Paul's Gentile apostolate as an instrument for the ushering in of the epoch when (as Paul combines the two Old Testament passages quoted above) 'the Deliverer shall come out of Zion, and shall turn away ungodliness from Jacob' (Rom. I r:26). Not only did the gospel first go out into all the world from Jerusalem; Jerusalem (if this reading of Paul's language is correct) would be the scene of its glorious consummation.

${ }^{78}$ Cf. Rom. 1 5:24, 28. 